\title{
2013 Radiological
} Monitoring Results Associated with the Advanced Test Reactor Complex Cold Waste Pond

Michael G. Lewis

February 2014

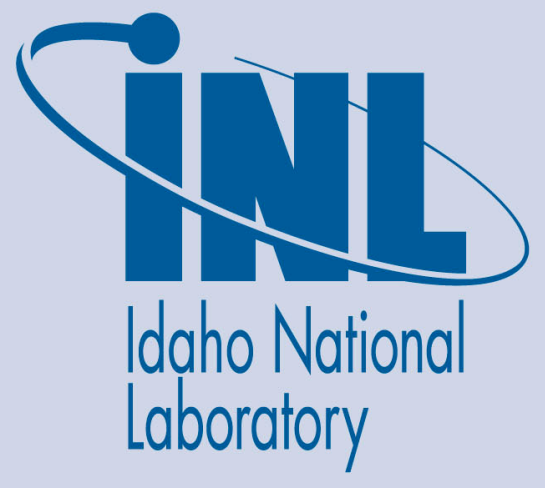

The INL is a U.S. Department of Energy National Laboratory operated by Battelle Energy Alliance 
INL/EXT-13-30964

\title{
2013 Radiological Monitoring Results Associated with the Advanced Test Reactor Complex Cold Waste Pond
}

\author{
Michael G. Lewis
}

February 2014

Idaho National Laboratory
Idaho Falls, Idaho 83415

http://www.inl.gov

Prepared for the

U.S. Department of Energy

Office of Nuclear Energy

Under DOE Idaho Operations Office

Contract DE-AC07-05ID14517 



\begin{abstract}
This report summarizes radiological monitoring performed of the Idaho National Laboratory Site's Advanced Test Reactor Complex Cold Waste wastewater prior to discharge into the Cold Waste Pond and of specific groundwater monitoring wells associated with the Industrial Wastewater Reuse Permit (\#LA-000161-01, Modification B). All radiological monitoring is performed to fulfill Department of Energy requirements under the Atomic Energy Act.
\end{abstract}




\section{CONTENTS}

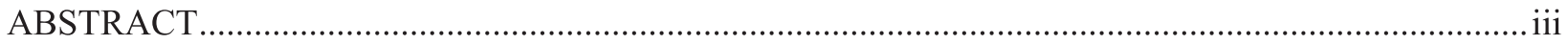

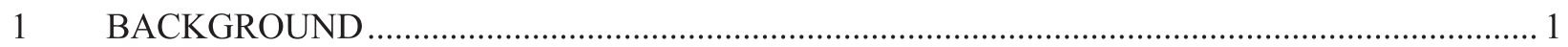

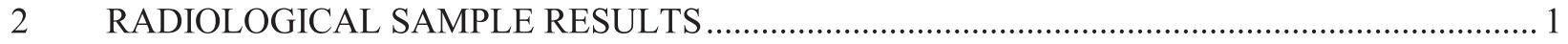

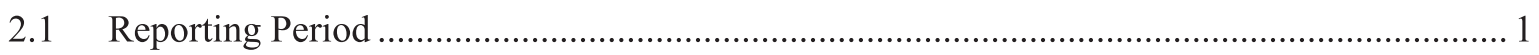

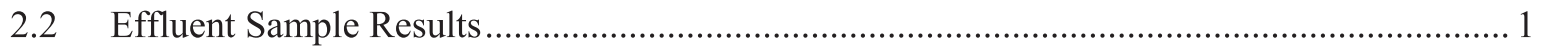

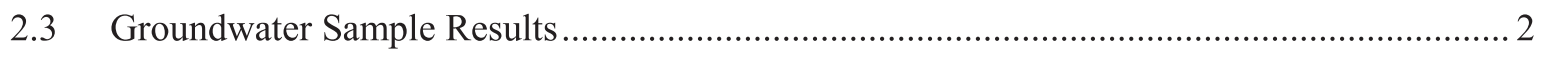

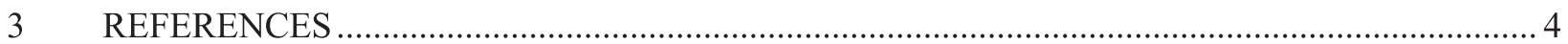

\section{TABLES}

Table 1. Advanced Test Reactor Complex Cold Waste Pond effluent gross alpha and gross beta radiological results for the period of November 2012 through October 2013.

Table 2. Gross alpha, gross beta, and tritium results from samples collected in April and October 2013 from the Advanced Test Reactor Complex Cold Waste Pond Industrial

Wastewater Reuse Permit monitoring wells. 


\section{Radiological Monitoring Results Associated with the Advanced Test Reactor Complex Cold Waste Pond}

\section{BACKGROUND}

The radiological information presented in this report is provided based upon an agreement between the Idaho Department of Environmental Quality and the U.S. Department of Energy Idaho Operations Office. This report fulfills the terms of agreement documented in the current Industrial Wastewater Reuse Permit (IWRP) \#LA-000161-01 for the Idaho National Laboratory Site's Advanced Test Reactor Complex (ATR Complex, formerly Reactor Technology Complex) Cold Waste Pond (CWP). The IWRP was issued on February 26, 2008 (Johnston 2008) and modified (Modification B) on August 20, 2008 (Eager 2008).

As stated in Section H ("Standard Reporting Requirements"), items 6 and 7 of the IWRP:

- The permittee agrees to provide to the Department the results of radiological monitoring of the effluent, prior to discharge into the percolation pond, with respect to the INL-ATR Complex Cold Waste Pond that is performed to fulfill Department of Energy requirements under the Atomic Energy Act. The permittee agrees to provide the results with the Annual Report.

- The permittee agrees to provide to the Department the results of ground water radiological monitoring with respect to the INL-ATR Complex Cold Waste Pond that is performed to fulfill Department of Energy requirements under the Atomic Energy Act. The permittee agrees to provide the results with the Annual Report.

\section{RADIOLOGICAL SAMPLE RESULTS}

\subsection{Reporting Period}

For the ATR Complex CWP, this IWRP reporting year runs from November 1, 2012-October 31, 2013. As stated in the "Facility Monitoring Table" of Section G of the IWRP, groundwater sampling shall be conducted in April and October each year. Therefore, the groundwater results presented will be from the April and October 2013 sampling events.

\subsection{Effluent Sample Results}

Samples were collected to satisfy the surveillance objectives of DOE Order 450.1A and the release objectives of DOE Order 458.1.

Monthly composite samples were collected from TRA-764 (WW-016101) using a flow proportional composite sampler. The monthly composite samples were analyzed by gamma spectrometry, and for gross alpha and gross beta. If the gross beta activity were to exceed $15 \mathrm{pCi} / \mathrm{L}$, a contingency analysis for strontium-90 would be performed on the sample. For this reporting year, the gross beta level of $15 \mathrm{pCi} / \mathrm{L}$ was exceeded in the December 2012 sample. However, strontium-90 was not detected in the December sample.

Beginning with the June 2013 sampling event, contingency analyses for radium-226 and radium-228 were performed if the gross alpha activity in the sample exceeded $5 \mathrm{pCi} / \mathrm{L}$. No contingency analyses for radium were required. 
Additional iodine-129, strontium-89/90, and tritium analyses were performed on the sample collected in October 2013. The results for these radionuclides were reported as undetected by the laboratory.

All monthly gamma spectrometry results were reported as undetected with the exception of the December 2012 potassium-40 sample with an activity level of $39.2 \mathrm{pCi} / \mathrm{L}$ and the February 2013 field duplicate sample at $29.1 \mathrm{pCi} / \mathrm{L}$. Potassium-40 was not detected in the initial February sample. Potassium40 is a naturally occurring isotope of potassium and has been detected occasionally in samples collected in previous years.

Table 1 shows the monthly gross alpha and gross beta results. Positive detections are considered measurements exceeding the instrument's minimum detection level and greater than two times the uncertainty.

Table 1. Advanced Test Reactor Complex Cold Waste Pond effluent gross alpha and gross beta radiological results for the period of November 2012 through October 2013.

\begin{tabular}{|c|c|c|}
\hline Sample Month & Gross Alpha (pCi/L) & Gross Beta (pCi/L) \\
\hline November 2012 & ND $^{\mathrm{a}}$ & $7.39( \pm 1.4)^{\mathrm{b}}$ \\
\hline December 2012 & ND & $15.8( \pm 1.79)$ \\
\hline January 2013 & ND & $9.65( \pm 1.12)$ \\
\hline February 2013 & ND & $2.86( \pm 0.926)$ \\
& ND $^{\mathrm{c}}$ & $3.26^{\mathrm{c}}( \pm 0.948)$ \\
\hline March 2013 & ND & ND \\
\hline April 2013 & ND & $10.2( \pm 1.56)$ \\
\hline May 2013 & $2.8( \pm 0.637)$ & $4.49( \pm 0.899)$ \\
\hline June 2013 & ND & $14.2( \pm 1.58)$ \\
\hline July 2013 & ND & ND \\
\hline August 2013 & $2.02( \pm 0.721)$ & ND \\
\hline September 2013 & ND & $13.8( \pm 1.09)$ \\
\hline October 2013 & ND & $4.89( \pm 0.77)$ \\
\hline $\begin{array}{l}\text { a. ND }- \text { Not detected. } \\
\text { b. One sigma uncertainty shown in parenthesis. } \\
\text { c. Duplicate sample result. }\end{array}$ & & \\
\hline \multicolumn{2}{|l}{} & \\
\hline
\end{tabular}

\subsection{Groundwater Sample Results}

Samples were collected to satisfy the surveillance objectives of DOE Order 450.1A and release objectives of DOE Order 458.1.

Groundwater samples for radiological parameters were collected from aquifer wells Middle-1823, TRA-07, TRA-08, USGS-065, and USGS-076 in April and October 2013. A field duplicate sample was collected from USGS-0065 on October 8, 2013. Samples were analyzed by gamma spectrometry, and for gross alpha, gross beta, tritium, and strontium- 90 .

Only gross alpha, gross beta, and tritium were positively detected in the April and/or October samples (Table 2). Positive detections are considered measurements exceeding the instrument's minimum detection level and greater than two times the uncertainty. 
Table 2. Gross alpha, gross beta, and tritium results from samples collected in April and October 2013 from the Advanced Test Reactor Complex Cold Waste Pond Industrial Wastewater Reuse Permit monitoring wells.

\begin{tabular}{|c|c|c|c|}
\hline Monitoring Well & Sample Date & Parameter & $\begin{array}{c}\text { Sample Result } \\
(\mathrm{pCi} / \mathrm{L})\end{array}$ \\
\hline \multirow[t]{6}{*}{ USGS-065 } & $04 / 17 / 13$ & Gross Alpha & $1.12( \pm 0.399)^{\mathrm{a}}$ \\
\hline & & Gross Beta & $4.43( \pm 0.713)$ \\
\hline & & Tritium & $2,930( \pm 349)$ \\
\hline & $10 / 08 / 13$ & Gross Alpha & $\begin{array}{c}2.84( \pm 0.749) \\
\mathrm{ND}^{\mathrm{b}, \mathrm{c}} \\
\end{array}$ \\
\hline & & Gross Beta & $\begin{array}{c}5.32( \pm 1.04) \\
3.39^{\mathrm{b}}( \pm 0.799)\end{array}$ \\
\hline & & Tritium & $\begin{array}{r}2,890( \pm 343) \\
3,130^{b}( \pm 368)\end{array}$ \\
\hline \multirow[t]{6}{*}{ TRA-07 } & $04 / 18 / 13$ & Gross Alpha & $4.11( \pm 1.2)$ \\
\hline & & Gross beta & $5.9( \pm 1.36)$ \\
\hline & & Tritium & $7,390( \pm 787)$ \\
\hline & $10 / 08 / 13$ & Gross Alpha & $6.29( \pm 1.18)$ \\
\hline & & Gross Beta & $9.96( \pm 0.993)$ \\
\hline & & Tritium & $7,200( \pm 768)$ \\
\hline \multirow[t]{6}{*}{ TRA-08 } & $04 / 18 / 13$ & Gross Alpha & ND \\
\hline & & Gross Beta & $3.5( \pm 0.731)$ \\
\hline & & Tritium & $1,250( \pm 182)$ \\
\hline & $10 / 07 / 13$ & Gross Alpha & ND \\
\hline & & Gross Beta & $9.75( \pm 1.06)$ \\
\hline & & Tritium & $1,360( \pm 193)$ \\
\hline \multirow[t]{6}{*}{ USGS-076 } & $04 / 17 / 13$ & Gross Alpha & ND \\
\hline & & Gross Beta & ND \\
\hline & & Tritium & $397( \pm 102)$ \\
\hline & $10 / 07 / 13$ & Gross Alpha & ND \\
\hline & & Gross Beta & ND \\
\hline & & Tritium & $561( \pm 113)$ \\
\hline \multirow[t]{6}{*}{ Middle-1823 } & $04 / 17 / 13$ & Gross Alpha & ND \\
\hline & & Gross Beta & $2.86( \pm 0.638)$ \\
\hline & & Tritium & $960( \pm 153)$ \\
\hline & $10 / 07 / 13$ & Gross Alpha & ND \\
\hline & & Gross Beta & $2.42( \pm 0.715)$ \\
\hline & & Tritium & $725( \pm 129)$ \\
\hline
\end{tabular}




\section{REFERENCES}

42 USC § 2011-2259, 1954, “Atomic Energy Act of 1954,” United States Code.

DOE Order 450.1A, June 4, 2008, "Environmental Protection Program," U.S. Department of Energy.

DOE Order 458.1, February 11, 2011, "Radiation Protection of the Public and the Environment," U.S. Department of Energy.

Eager, G., DEQ, to W. Hamel, DOE-ID, August 20, 2008, "Minor Modification B, Facility Name Change from Reactor Technology Complex (RTC) to Advanced Test Reactor Complex (ATR Complex), Cold Waste Pond, Wastewater Reuse Permit No. LA-000161-01," CCN 214687.

Johnston, J., DEQ, to W. Hamel, DOE-ID, February 26, 2008, "Reactor Technology Complex (RTC) Cold Waste Pond, Wastewater Reuse Permit No. LA-000161-01 (Industrial Wastewater)," CCN 212842 . 